\title{
Penerapan Metode Demonstrasi Untuk Mengurangi Kesulitan Memahami Teks Percakapan pada Mata Pelajaran Bahasa Indonesia Kelas IV SDN Kidalang
}

\author{
Tati Nurhayati ${ }^{1)}$ Evi Oktaviani Rukmana ${ }^{2)}$ \\ 1) SD Negeri Yudha, Indonesia \\ 2) SMP Negeri 2 Jawilan, Indonesia \\ E-mail:devioktavianirukmana@gmail.com
}

\begin{abstract}
Abstrak. Upaya mengembangkan sikap dan keterampilan peserta didik merupakan tuntutan yang tak terpisahkan dari tugas dan tanggung jawab guru dalam melaksanakan PBM (proses belajar mengajar). Dalam melaksanakan proses belajar mengajar yang harus dikuasai guru erat kaitannya dengan penggunaan metode dan alat peraga yang sesuai dengan materi pelajarannya. Kemampuan komunikasi sangat diperlukan karena mampu mendorong seseorang untuk aktif, dapat membangun gagasan, ide, dan konsep. Sehingga siswa dapat mengembangkan skil-skilnya dalam proses pembelajaran. Hal tersebut sesuai dengan tuntutan dalam mempelajari Pelajaran Bahasa Indonesia di sekolah. Namun, pada kondisi pembelajaran di sekolah saat ini masih menunjukkan rendahnya kemampuan komunikasi percakapan bahasa siswa. Salah satu alternatif pembelajaran yang dapat meningkatkan kemampuan percakapan bahasa indonesia siswa adalah pembelajaran menggunakan Metode demontrasi. Penelitian ini bertujuan untuk mengetahui kemampuan percakapan siswa yang menggunakan metode demontrasi, untuk mengetahui kualitas peningkatan kemampuan percakapan siswa yang memperoleh pembelajaran dengan menggunakan metode demontrasi. Penelitian ini merupakan penelitian tindakan kelas. Penelitian ini dilaksanakan di SDN Kidalang siswa kelas IV tahun. Berdasarkan data hasil penelitian, diperoleh kesimpulan bahwa kemampuan memahami teks percakapan siswa mengalami peningkatan setelah menggunakan metode demontrasi pada pelajaran bahasa indonesia. Siswa menjadi lebih aktif dalam pembelajaran serta bersikap positif terhadap penggunaan metode demontrasi dalam pembelajaran Bahasa Indonesia. Metode demontrasibisa menjadi salah satu alternatif bagi guru untuk melakukan proses belajar mengajar di kelas.
\end{abstract}

Kata Kunci: demonstrasi, kemampuan memahami, teks percakapan

\section{PENDAHULUAN}

Isi pokok yang terkandung dari tujuan pendidikan nasional yang ada dalam Undang-Undang Sistem Pendidikan Nasional (UUSPN) diatas adalah pembentukan manusia Pancasilais yang utuh yang mempunyai karakteristik :

a. Beriman dan bertakwa kepada Tuhan Yang Maha Esa

b. Berpengetahuan luas

c. Terampil

d. Berbudi luhur

e. Sehat jasmani dan rohani

f. Berkepribadian yang mantap dan mandiri

g. Bertanggung Jawab kemasyarakatan dan kebangsaan.

Dengan demikian guru sebagai pelaksana disekolah, setiap menyusun perencanaan pengajaran dan dalam pelaksanaannya. Haruslah memperhatikan sifat dan tujuan pendidikan nasionalis tersebut.

Upaya mengembangkan sikap dan keterampilan peserta didik merupakan tuntutan yang tak terpisahkan dari tugas dan tanggung jawab guru dalam melaksanakan PBM (Proses Belajar Mengajar). Dalam melaksanakan proses belajar mengajar selain harus menguasai materi pembelajaran, guru pun hendaknya memiliki keterampilan dan teknik-teknik mengajar yang harus dikuasai guru erat kaitannya dengan penggunaan metode dan alat peraga yang sesuai dengan materi pelajarannya. Guru yang profesional senantiasa akan terus mencoba berbagai teknik belajar, dan menyajikan pelajaran sehingga pada akhirnya membantu siswa memahami materi pelajaran yang disajikan, terutama untuk pelajaran yang dianggap sulit oleh siswa seperti Sains dan Bahasa Indonesia.

Untuk memfasilitasi agar pengembgan sikap dan keterampilan peseta didik tercapai, maka peneliti memilih menggunakan metode demonstrasi. Metode demontrasi dipilih karena menambah aktivitas belajar siswa karena ia turut melakukan kegiatan peragaan, efisiensi waktu belajar, memperbesar peluang terciptanya hasil belajar yang lebih mantap, lebih mampu membantu siswa yang tertinggal penguasaan materi ajarnya, membangkitkan minat dan aktivitas belajar serta memberikan pemahman yang lebih tepat dan jelas.

Tujuan pokok penggunaan metode demontrasi dalam proses belajar mengajar ialah untuk memperjelas pengertian konsep dan memperlihatkan (meneladani) cara melakukan sesuatu atau proses terjadinya sesuatu. Demonstrasi adalah metode mengajar dengan cara memperagakan barang, kejadian, aturan dan urutan melakukan suatu kegiatan, baik secara langsung maupun melalui penggunaan media pengajaran yang relevan dengan poko bahasan atau materi yang sedang disajikan. 
Dari pengalaman penulis memberikan materi Bahasa Indonesia di kelas IV SDN Kidalang, ternyata masih banyak siswa yang mengalami kesulitan dalam memahami teks percakapan terutama siswa lebih kesulitan ketika memperaktekan kalimat percakapan dengan mimik yang kurang sesuai bahkan tidak sesuai.

\section{METODE}

Penelitian ini merupakan penelitian tindakan kelas. Proses pengambilan data sekaligus perbaikan proses belajar mengajar di kelas IV SDN Kidalang Kec. Bandung, Kab.Serang, Banten dari tanggal 17 Maret sampai 25 Maret 2009. Proses treatment yangdiberikan dibagi menjadi tiga tahapan, yaitu Pra-Siklus, Siklus I dan Siklus II.

Perbaikanpembelajaran ini dilaksanakan di kelas IV SDN Kidalang Kec. Bandung Kabupaten Serang. Adapun pelaksanaan pembelajaran dilaksanakan mulai tanggal 17-25 Maret 2009. Sebelum dimulainya siklus, peneliti menyiapkan peragaan alat sebagai pendahuluan untuk melatih siswa (prasiklus) dengan rincian sebagai berikut.

a. Membuat rencana perbaikan pembelajaran

b. Menyiapkan siswa

c. Meminta bantuan teman sejawat untuk mengamati prosess perbaikan pembelajaran.

d. Melaksanakan perbaikan pembelajaran

Hasil yang diperoleh dianalisis per siswa. Instrumen yang dipakai berupa tes hasil belajar. Tes hasil belajar dibuat oleh peneliti sehingga tes perlu diuji kevalidan dan reliabilitasnya.

\section{HASIL DAN PEMBAHASAN}

Bagian prasiklus memberikan informasi bahwa pembimbingan siswa oleh guru berdasarkan barang-barang yang ada di sekitar siswa sehari-hari. Pada bagian Siklus I, diketahui bahwa siswa telah mampu menggolongkan hewan berdasarkan jenis makannya, siswa telah mampu memberi contoh nama hewan yang ada disekitar lingkungan siswa. Dalam Siklus I, siswa mengalami kesulitan saat mengerjakan tes evaluasi mengenai hewan dan makanannya Langkahlangkah yang ditempuh selama pelaksanakan perbaikan pembelajaran Pra-Siklusadalah sebagai berikut.

a. Menyiapkan alat peraga

b. Membimbing siswa mengenai cara mudah dalam menggolongkan hewan berdasarkan jenis makanannya, dengan memberi contoh hewan yang ada disekitar lingkungan mereka sehingga mudah dikenal dan dimengerti.

c. Lebih banyak memberikan latihan soal

d. Mengajukan pertanyaan-pertanyaan kepada siswa

e. Memberi motivasi kepada siswa

Pada Siklus II, diadakan sedikit perbaikan treatment akibat adanya masalah pada siklus I. Guru memberikan penjelasan tentang hewan dan makanannya menggunakan media atau alat peraga. Cara ini efektif karena siswa mampu menggolongkan hewan berdsarkan jenis makanannya. Pada Siklus II pula, peneliti mencoba menambahkan metode tanya jawab sebagai pendmping demonstrasi. Metode tanya jawab dipilih karena dapat mengetahui kemampuan siswa terhadap materi hewan dan makanannya.

Langkah-langkah yang ditempuh dalam perbaikan pembelajaran sikus I adalah sebagai berikut.

a. Sebelum mengajar teks percakapan, hendaknya guru memberikan penjelasan bahwa dakam belajar teks percakapan, terlebih dahulu harus memahami apa isi dari teks tersebut.

b. Siswa secara bergiliran belajar berpencar menjadi pelaku dalam teks percakapan tersebut.

c. Langkah-langkah yang harus diempuh dalam siklus II sebagai berikut.

d. Memberikan beberapa pertanyaan mengenai materi pembelajaran

e. Pengajaran dan bimbingan guru kepada siswa hanya difokuskan kepada 4 orang siswa yang kurang memiliki keberanian dalam belajar terutama dalam berperan menjadi pelaku pada teks percakapan.

f. Memberikan tugas rumah

Secara ringkas, dengan perbaikan pada tiap siklus, hasil belajar mengalami peningkatan. Dengan nilai terendah pada pra siklus $=30$, siklus $1=50$ dan siklus $I I=60$. Untuk sajian lebih lengkap, dapat dilihat pada Gambar 1.

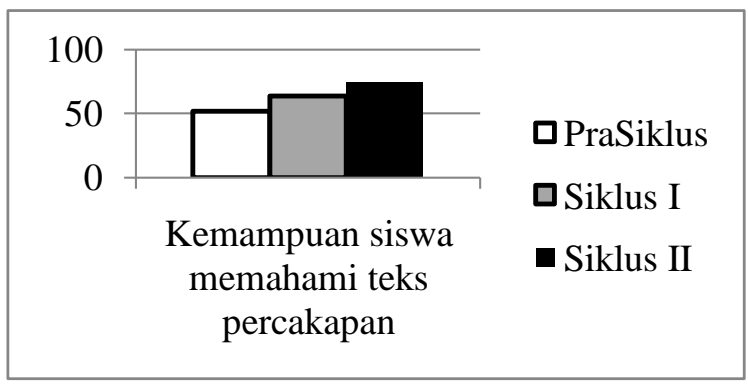

Gambar 1. Grafik kemampuan siswa memahami teks percakapan

Pada pelaksanaan perbaikan pembelajaran, guru merubah strategi yang pada awalnya hanya penjelasan-penjelasan saja, diubah menjadi penjelasan yang terperinci dan menggunakan alat peraga.

Pada awalnya cara belajar yang dilakukan hanya DDCH (duduk, dengar, catat, hafal) diubah menjadi model CBSA (cara belajar siswa aktif). Metode yang digunakan hanya ceramah dan tanya jawab, maka dari itu ditambah dngan beberapa macam metode diantaranya demonstrasi, penugasan, pemecahan masalah (problem solving) penugasan kelas sudah lebih baik dan menyeluruh. Materi pelajaran/alat peraga yang pada awalnya hanya terbatas pada buku sumber, sekarang sudah ditambah dengan audiovisual berupa tape.

Menurut Piaget, anak pada usia 7-11 tahun yaitu tahap operasi konkrit, pada tahap ini anak-anak menggunakan konsep dan teori untuk memilih dan membutuhkan contoh yang terlihat jelas, sehingga pada perbaikan pembelajaran ini, guru menggunakan alat peraga supaya anak lebih mudah memahami dan mengingat suatu konsep.Menurut Suciati, 1990 terdapat hubungan antara tingkat motivasi belajar, baik terhadap hasil belajar pada suatu waktu tertentu, maupun 
terhadap hasil belajar selanjutnya. Meece dan Blumenfeld. 1987, tingkat motivasi belajar cenderung berkorelasi positif dengan hasil belajar. Artinya semakin kuat/tinggi tingkat motivasi belajar, semakin baik hasil belajar siswa. Demikian pula hasil belajar yang baik nampaknya juga berpengaruh terhadap hasil belajar berikutnya. Oleh karena itu pada proses perbaikan pembelajaran ini hendaknya guru selalu memberi motivasi kepada siswa supaya mendapat hasil yang terbaik atau ada perubahan dari siklus menjadi lebih baik lagi.

\section{KESIMPULAN DAN SARAN}

\section{KESIMPULAN}

Setelah selesai melakukan perbaikan mata pelajaran Sains mengenai hewan dan makanannya, selama 2 siklus dalam waktu yang berbeda kami dapat menarik kesimpulan diantaranya; Dengan menggunakan alat peraga yang tepat dan sesuai pembelajaran, dengan itu anak akan lebih termotivasi.Dengan diberikannya penguatan kepada siswa, maka pencapaian nilai siswa menjadi meningkatDengan metode yang bervariasi maka terjadi interaksi yang baik antara guru dengan siswa.
Guru sebagai fasilitator harus senantiasa memahami kemampuan yang dimiliki masing-masing siswa, untuk meningkatkan pemahaman siswa dalam materi pembelajaran, guru hendaknya memperhatikan hal-hal sebagai berikut:

a. Penggunaannya metode pembelajaran bervariasi

b. Siswa dilibatkan secara aktif dalam proses pembelajaran

c. Penggunaan alat peraga yang tepat

d. Memotivasi anak dengan memberikan penguatan

\section{DAFTAR PUSTAKA}

[1] Animaous (2004) Kurikulum Berbasis Kompetensi Depniknas, Jakarta.

[2] Aswan, at ai, (2004) Bina Bahasa dan Sastra Indonesia Kelas 4 Sekolah Dasar, Cipta Prima Budaya Jakarta.

[3] Departemen Pendidikan Nasional (2004) Kurikulum Pendidikan Dasar. Jakarta

[4] Kemala Resa (2006) Jelajah IPA Kelas 4 Sekolah Dasar Yudistira, Jakarta.

[5] Sarwono Hadi, al al, Kursus Pendalaman Materi IPA-SLU Unit Implementasi Program Bersama. UNDP, ITB

[6] Suciati, Dr. At ai, (2004) Belajar dan Pembelajaran 2. Pusat Pendidikan Universitas Terbuka.

[7] Wardani, LG. A.K. Prof at al, (2004) Penelitian Tindakan Kelas. Jakarta

[8] Wardani, L.G.A.K. Dr. Prof at al, (2005) Pemantapan Kemampuan Profesional. Universitas Terbuka 